\title{
Postnatal Variation of Limb Bones in the Japanese Quail, Coturnix coturnix japonica
}

\author{
Variación Postnatal de Huesos de los Miembros en la \\ Codorniz Japonesa, Coturnix coturnix japonica
}

Yaru Ren*; Huan Wang* \& Zihui Zhang*

REN, Y.; WANG, H. \& ZHANG, Z. Postnatal variation of limb bones in the Japanese quail, Coturnix coturnix japonica. Int. J. Morphol., 34(2):708-712, 2016.

SUMMARY: Changes in body size over ontogeny may influence the ontogenetic development of long bones, and thus important to our understanding of variation in morphological, physiological, and life-history traits within species. In this study, we sample the entire measurements of the Japanese quail (Coturnix coturnix japonica) of individual skeletons, to investigate the ontogenetic allometry of limb bone proportions by Reduced Major Axis (RMA) regression. The ulna and humerus were both positively allometric in relation to body mass, with their proximal ends growth more rapidly than other regions. Hindlimb bones exhibited more than one allometric pattern. The tarsometatarsus was negative; the femur presented positive allometry, with the width and depth of the proximal end scaled more strongly; measurements of the tibiotarsus were dominated by more rapid growth, especially the width of the proximal end. The growth patterns are suggested to be correlated with the ontogeny of behavior, and reflect the muscular requirements for different mode of locomotion.

KEY WORDS: Ontogenetic allometry; Forelimb; Hindlimb; Japanese quail; Precocial.

\section{INTRODUCTION}

Variation and covariation of long bone with body mass is a fascinating issue in biological scaling (Klingenberg \& Zimmermann, 1992). One of the approaches to the assessment of patterns of character covariation is allometry which has attracted a great deal of attention in extant species, and is very useful in assessing ontogenetic stage or distinguishing multiple taxa of fossil materials (Houck et al., 1989). Allometric relationships may result from natural selection for functional optimization, and reflect strong physical, physiological, or other biological mechanisms that constrain the rate and direction of evolution (Pélabon et al., 2014). Because body size can vary with age or developmental stage, across individuals, and across species, three types of allometry have been defined: ontogenetic, static, and evolutionary allometry (Klingenberg \& Zimmermann; Pélabon et al.). Limb bone in tetrapods is crucial for foraging, behavioral thermoregulation, and escape from predation (Hayward et al., 2008). As reported in a lot of researches (e.g. Simons, 2010), with the change of body size, fore- and hind limb show different allometric relationships between species, which may correlated to the locomotor style, degree of precociality/ altriciality and life history.
Unlike other tetrapods, birds are exclusively bipedal with their forelimbs modified into wings for flight, and hindlimbs primarily for walking. New hatchlings vary in the way they develop and present wide variations in musculoskeletal development in different bird species (Stark \& Ricklefs, 1998). One extreme is altricial species which are naked, blind, and virtually immobile when they hatch, and thus are completely dependent on their parents. In contrast, precocial chicks are well developed usually covered with fuzzy down, possess thermogenic independence and the ability to forage and avoid predators. Precocial species rely on locomotion both over ground and in the air from hatchling to adult. Japanese quail, for example, could run rapidly on the first day of post-hatching life, acquired functional use of forelimb within the first week, began to fly at 30 days and could maintain level flight at 60 days (Ricklefs, 1979).

Changes in body size over ontogeny may influence the ontogenetic development of long bones. Previous work on allometry in birds has paid more attention at interspecific level (e.g. Simons), and generally restricted to an examination of element length; ontogenetic variation and 
covariation of forelimb and hindlimb are relatively rare (Green et al., 2001; Picasso, 2012). Insight into the growth patterns of fore- and hind limb bones and their relationship with the ontogeny of locomotion is critical to our understanding of variation in morphological, physiological, and life-history traits within and among species.

The Japanese quail (Coturnix coturnix japonica) is classified as precocial and is one of the favoured animal models in behavioural, comparative and developmental studies (Ainsworth et al., 2010). Till now, there isn't a report on the ontogenetic allometry of this species. Because superstructures, such as ridges, tuberosities and condyles on both ends of long bone, are necessary for the attachment of muscles, tendons and ligaments, thus influencing musculoskeletal functionality. In this study, we use entire bone measurements including the width and depth of the proximal and distal ends, rather than the traditional focus on the length and midshaft width to investigate the variation of long bones and its functional implications during ontogeny.

\section{MATERIAL AND METHOD}

Two hundred and eighty quails were obtained from a commercial quail farm located in the suburb of Beijing, China. Selected birds were healthy and were reared in semiextensive conditions. Birds were sacrificed and body masses were taken with a digital balance $(0.01 \mathrm{~g}$ precision and capacity of $510 \mathrm{~g}$ ) at the age of $8,11,14,17,20,23,27,31$, $35,42,49,65,97,134$ days. We take 20 quails every time, male and female are both included. Samples were collected from May 2014 to September 2014.

Skeletal specimens were prepared, and a total of 25 linear measurements of the ulna, humerus, femur, tibiotarsus and tarsometatarsus were selected (Table I). All measurements were made with a 150 -mm digital caliper (0.01 mm precision). Reduced major axis (RMA) regression was performed to investigate the relationship between body mass and linear measurement of the limb bone. All

Table I. Measurements of the fore- and hind limb bones.

\begin{tabular}{|c|c|}
\hline Humerus & $\begin{array}{l}\text { Hl: total humerus length, between extreme points of the proximal and distal regions. } \\
\text { Hum: latero-medial diameter of mid- shaft of the humerus } \\
\text { Hut: latero-medial width of proximal end, taken between extreme points. } \\
\text { Hup: antero-posterior width of proximal end, taken between extreme points. } \\
\text { Hua: antero-posterior width of condylus humeri lateralis. } \\
\text { Huc: antero-posterior width of condylus humeri medialis. }\end{array}$ \\
\hline Ulna & $\begin{array}{l}\text { Ul: total ulna length, between extreme points of the proximal and distal regions. } \\
\text { Umd: latero-medial diameter of mid- shaft of the ulna } \\
\text { Uew: latero-medial width of proximal end, taken between extreme points. } \\
\text { Ueh: antero-posterior width of proximal end, taken from the most extreme point of olecranon process to the } \\
\text { most extreme point of coronoid process. } \\
\text { Ust: antero-posterior width of the distal end taken extreme points of both condylus of ulna. }\end{array}$ \\
\hline Femur & $\begin{array}{l}\text { Ft: total femoral length, between extreme points of the proximal and distal regions. } \\
\text { Fem: latero-medial diameter of mid- shaft of the femur } \\
\text { Fet: latero-medial width of proximal femoral end, between lateral surface of trochanter and caput femoris. } \\
\text { Fep: antero-posterior width of proximal end, between trochanter and caput femoris. } \\
\text { Fea: antero-posterior width of condylus femoralis lateralis. } \\
\text { Fec: antero-posterior width of condylus femoralis medialis. }\end{array}$ \\
\hline Tibiotarsus & $\begin{array}{l}\text { Tl: tibiotarsus length, taken between extreme points of the proximal articular surface and the distal region. } \\
\text { Tim: latero-medial diameter of mid- shaft of the tibiotarsus } \\
\text { Tia: antero-posterior width of the proximal end, from the most extreme point of crista cnemialis cranialis to } \\
\text { the most extreme point of the caudal edge. } \\
\text { Til: latero-medial width of the proximal end, taken between extreme points. } \\
\text { Tic: latero-medial width of the distal end taken between extreme points of both condylus of tibiotarsus. } \\
\text { Tid: antero-posterior width of the distal end taken between extreme points. }\end{array}$ \\
\hline Tarsometatarsus & $\begin{array}{l}\text { Tat: total tarsometatarsus length, taken between extreme points of the proximal and the distal regions. } \\
\text { Tad: latero-medial diameter of mid- shaft of the tarsometatarsus } \\
\text { Tap: latero-medial width of the proximal end taken extreme points of both cotyla. } \\
\text { Tpp: antero-posterior width of the proximal end, taken from the most extreme point of hypotarsus to the } \\
\text { most extreme point of anterior edge. } \\
\text { Tam: latero-medial width of the distal end. }\end{array}$ \\
\hline
\end{tabular}


measurements were $\log 10$ transformed. RMA lines were expressed with equations in the form of $\log y=a+b \log x$, where $\mathrm{b}$ is the slope or coefficient of allometry that represents the ratio of specific growth rates, a is the y-intercept, $y$ is the measurement of the component being measured, and $\mathrm{x}$ is the body mass. Under a geometric similarity model, isometry is indicated by slopes not significantly different from 0.33 , positive allometry by slopes significantly greater than 0.33 , and negative allometry by slopes significantly less than 0.33 .

\section{RESULTS}

Relationships of the variables with body mass calculated from lined regressions of logarithmic data are presented in Table II. The two forelimb bones, ulna and humerus, were both positively allometric in relationship to body mass, with their proximal ends, such as the latero-medial width of the proximal ulna (Uew), the antero-posterior width of the proximal ulna (Ueh), the latero-medial width of proximal humerus (Hut) and antero-posterior width of the proximal humerus (Hup), scaled more strongly than other regions.
The three different hindlimb bones presented different relationship with the change of body mass. The femur showed positive allometry in the total femoral length $(\mathrm{Ft})$, the latero-medial diameter of midshaft (Fem), the lateromedial width of proximal end (Fet) and the antero-posterior width of proximal end (Fep). The slops of Fet and Fep were 0.41 , highest among measurements mentioned above.

The tibiotarsus showed two allometric relationships. The total length (Tl), the latero-medial diameter (Tim), the latero-medial width of the proximal end (Til) and the anteroposterior width of the distal end (Tid) scaled with positive allometry, whereas the antero-posterior width of the proximal end (Tia) and the latero-medial width of the distal end (Tic) scaled with negative allometry. Among positive allometry, the slope of latero-medial width of the proximal end (Til) was 0.57 , the highest.

The tarsometatarsus presented obviously negative allometry, except the antero-posterior width of the proximal end (Tpp) which was isometric.

$\mathrm{R}^{2}$-value ranged from 0.64 to 0.95 .

Table II. Results of allometric analyses with $95 \%$ CI.

\begin{tabular}{|c|c|c|c|c|c|c|c|}
\hline Bone & Measures & $R^{2}$ & $\mathbf{P}$ & b & Lower CI & Upper CI & $\mathbf{a}$ \\
\hline Ulna & Ul & 0.87 & 0.000 & $0.38^{*}$ & 0.37 & 0.40 & 0.67 \\
\hline \multirow[t]{4}{*}{$(\mathrm{n}=277)$} & Umd & 0.92 & 0.000 & $0.42^{*}$ & 0.40 & 0.43 & -0.46 \\
\hline & Uew & 0.92 & 0.000 & $0.41^{*}$ & 0.39 & 0.42 & -0.31 \\
\hline & Ueh & 0.94 & 0.000 & $0.55^{*}$ & 0.53 & 0.57 & -0.47 \\
\hline & Ust & 0.79 & 0.000 & $0.35^{*}$ & 0.33 & 0.37 & -0.12 \\
\hline \multirow{6}{*}{$\begin{array}{l}\text { Humerus } \\
(n=273)\end{array}$} & $\mathrm{Hl}$ & 0.89 & 0.000 & $0.38^{*}$ & 0.37 & 0.40 & 0.75 \\
\hline & Hum & 0.93 & 0.000 & $0.36^{*}$ & 0.35 & 0.37 & -0.31 \\
\hline & Hut & 0.85 & 0.000 & $0.50^{*}$ & 0.48 & 0.53 & -0.10 \\
\hline & Hup & 0.83 & 0.000 & $0.49^{*}$ & 0.47 & 0.52 & -0.13 \\
\hline & Hua & 0.92 & 0.000 & $0.39^{*}$ & 0.38 & 0.40 & -0.05 \\
\hline & Huc & 0.86 & 0.000 & $0.38^{*}$ & 0.36 & 0.40 & -0.19 \\
\hline \multirow{6}{*}{$\begin{array}{l}\text { Femur } \\
(n=269)\end{array}$} & $\mathrm{Ft}$ & 0.95 & 0.000 & $0.38^{*}$ & 0.37 & 0.39 & 0.78 \\
\hline & Fem & 0.90 & 0.000 & $0.36^{*}$ & 0.34 & 0.37 & -0.33 \\
\hline & Fet & 0.92 & 0.000 & $0.41^{*}$ & 0.39 & 0.42 & -0.05 \\
\hline & F ep & 0.92 & 0.000 & $0.41^{*}$ & 0.40 & 0.42 & -0.03 \\
\hline & Fea & 0.94 & 0.000 & 0.34 & 0.33 & 0.35 & 0.02 \\
\hline & $\mathrm{Fec}$ & 0.90 & 0.000 & 0.35 & 0.34 & 0.36 & -0.11 \\
\hline \multirow{6}{*}{$\begin{array}{l}\text { Tibiotarsus } \\
(\mathrm{n}=267)\end{array}$} & $\mathrm{T} 1$ & 0.93 & 0.000 & 0.35 & 0.34 & 0.37 & 0.92 \\
\hline & Tim & 0.91 & 0.000 & $0.42^{*}$ & 0.41 & 0.44 & -0.46 \\
\hline & Tia & 0.76 & 0.000 & $0.23^{*}$ & 0.21 & 0.24 & 0.23 \\
\hline & Til & 0.91 & 0.000 & $0.57^{*}$ & 0.55 & 0.59 & -0.37 \\
\hline & Tic & 0.83 & 0.000 & $0.20^{*}$ & 0.19 & 0.21 & 0.24 \\
\hline & Tid & 0.89 & 0.000 & $0.36^{*}$ & 0.35 & 0.38 & -0.14 \\
\hline \multirow{5}{*}{$\begin{array}{l}\text { Tarsometatarsus } \\
(\mathrm{n}=272)\end{array}$} & Tat & 0.89 & 0.000 & $0.29 *$ & 0.28 & 0.30 & 0.87 \\
\hline & Tad & 0.80 & 0.000 & $0.22^{*}$ & 0.21 & 0.23 & -0.09 \\
\hline & Tap & 0.64 & 0.000 & $0.17^{*}$ & 0.16 & 0.19 & 0.37 \\
\hline & Tpp & 0.83 & 0.000 & 0.34 & 0.32 & 0.36 & -0.02 \\
\hline & Tam & 0.84 & 0.000 & $0.22^{*}$ & 0.21 & 0.23 & 0.29 \\
\hline
\end{tabular}




\section{DISCUSSION}

The locomotor anatomy of birds is divided into distinct functional modules; most generally, the forelimbs are employed for flight, the hindlimbs for running and swimming (Gatesy \& Dial, 1996). In Japanese quail, all measurements of the forelimb present positive growth, with relative growth of the proximal ends of the humerus and ulna more rapid than the growth of the length and width of the bones. The high allometric exponents of the Hut, Hup, Ueh, Uew and Umd may reflect the requirments for flight: a thicker ulna reflect enhancement of bone strength; scaling change of Hut and Hup is mainly due to the development of a series of superstructures, such as internal and external tuberosities, bicipital and deltoid crests, which are necessary for the attachment of muscles, especially M. pectoralis and M. supracoracoideus, the most important flight muscles (Zhang \& Yang, 2013; Yang et al., 2015); rapid growth of Ueh and Uew suggest better development of some antebrachial muscles which are essential for takeoff and controlled landing (Dial, 1992). These growth patterns were consistent with the flight ability of quail chicks which acquired functional use of forelimb within the first week, began to fly at 30 days days (Ricklefs).

Hindlimbs of birds are responsible for terrestrial movements. Kinematic studies indicate that stride length and locomotor stability are mainly correlated with the distal segments, the tibiotarsus and tarsometatarsus (Verstappen et al., 2000; Stoessel et al., 2013). As a typical precocial species, quails hatched with relatively well developed tarsometatarsus, displaying a strong negative allometry relative to body mass, suggests that the terrestrial locomotion in the early postnatal period is achieved mainly by the tarsometatarsus and characterized by short stride length and swing phase; this result is concordant with the kinematic measurements (Muir et al., 1996), and indicates that young chicks escape from predation by short step locomotion.

Ontogenetic scaling of the limbs has important consequences for locomotor mechanics and life history strategies (Main \& Biewener, 2007). During ontogeny, there is a potential trade-off between energetic investment in growth of structures (i.e. body and limb size) and development of physiological function (e.g. cellular differentiation, muscle strength) that may constrain locomotor performance (Jackson et al.). Swinging the limbs is expensive, consuming $26 \%$ of the energy used by the limbs (Marsh et al., 2004). Mm. iliofibularis, femerotibialis, iliotibialis cranialis, iliotibialis lateralis, tibialis cranialis are active in swing phase. Except M. tibialis cranialis which is located in the cranial surface of the shank (tibiotarsus), other four muscles occupy the lateral and cranial parts of the thigh (femur) (Zhang et al., 2012). The positive allometry of the femur and the tibiotarsus reveals relatively short proximal segments of the leg, and less development of the swing-phase muscles in newly hatchlings, and thus reduce terrestrial locomotion cost, et al. one insufficient control of balance in the early ontogenetic growth (Muir et al.).

Given the fact that the growth of the proximal ends of the femur and tibiotarsus (Fet, Fep, Til) is more rapid than other measurements of the two bones. One might expect high loads of muscular and ligamentous insertions. The rapid growth of the width of the proximal femur is mainly resulted from the development of the major trochanter (Trochanter femoris), on which the obturator and iliotrochanteric muscles and certain ligaments insert. These muscles and ligaments are very important in maintaining the stability of the hip joint when the body is supported by only one limb during the stance phase (Hutchinson \& Gatesy, 2000). The strong positive allometric pattern $(b=0.57)$ in the proximal region of the tibiotarsus (Tia), as in the study of the greater rhea (Picasso), should be related to the enlargement and expansion of the cnemial crests and crista patellaris. The rapid increase of the tibiotarsus (e.g. the total length, the mid-shaft width and the width of the proximal end) make the bone relatively thicker in shaft and broader in proximal end, reflecting rapid development of a series of muscles controlling the movement of distal hindlimb, such as Mm. extensor digitorum longus, gastrocnemius, flexor digitorum longus, tibialis cranialis (Zhang et al., 2012). During ontogeny, scaling changes in femur and tibiotarsus, together with well-developed muscles are also important to flight, because most of the initial acceleration during the first wingbeat is produced by the legs (Robertson \& Biewener, 2012). Quails began to fly at 30 days and could maintain level flight at 60 days (Ricklefs), they may be ecologically or behaviorally adapted to walk up to a certain speed and then switch to flying by the aid of legs.

Comparing our work with published information in other birds (e.g. Ricklefs; Carrier \& Leon, 1990; Green et al.; Bennett, 2008; Picasso), it can be seen that allometric growth pattern in limb bones is variable. It is not surprising because: some researches were different in method, such as the sample size, the use of indirect versus direct measurements; the most important is that growth pattern of limb bones is influenced by a complex suite of factors and interactions, such as hatchingto-fledging time, changes in biomechanical stress, onset of locomotor activity, limb use and behavior during ontogeny (Hayward et al.), many of which remain incompletely understood.

ACKNOWLEDGEMENTS. We are grateful to Dong YY, Ma YJ, Kang Z, Wang Y, Wu HF for their help in sample collection. This work was supported by grant from the National Natural Science Foundation of China (31471951). 
REN, Y.; WANG, H. \& ZHANG, Z. Variación postnatal de huesos de los miembros en la codorniz japonesa Coturnix coturnix japonica. Int. J. Morphol., 34(2):708-712, 2016.

RESUMEN: Los cambios en el tamaño corporal sobre la ontogenia pueden influir en el desarrollo ontogenético de los huesos largos, y por lo tanto es importante conocer la variación en sus rasgos morfológicos, fisiológicos y la historia de vida dentro de las especies. En este estudio, se muestran las mediciones completas de esqueletos individuales de codorniz japonesa (Coturnix coturnix japonica), para investigar la alometría ontogenética de las proporciones de los huesos de los miembros mediante la regresión del Eje Mayor Reducido (RMA). La ulna y el húmero fueron ambos positivos alométricamente en relación a la masa corporal, con un crecimiento más ligero de sus extremos proximales que de otras regiones. Los huesos de los miembros posteriores mostraron más de un patrón alométrico. El tarsometatarsus fue negativo; el fémur presentó alometría positiva, con un ancho y profundidad del extremo proximal importantes. Las mediciones del tibiotarso presentaron un crecimiento más rápido, sobre todo la anchura del extremo proximal. Los patrones de crecimiento sugieren estar correlacionados con la ontogenia de la conducta, y reflejan los requisitos musculares para un modo de locomoción diferente.

PALABRAS CLAVE: Alometría ontogenética; Miembro anterior; Miembros posterior; Codorniz japonesa; Precoces.

\section{REFERENCES}

Ainsworth, S. J.; Stanley, R. L. \& Evans, D. J. Developmental stages of the Japanese quail. J. Anat., 216(1):3-15, 2010.

Bennett, M. B. Post-hatching growth and development of the pectoral and pelvic limbs in the black noddy, Anous minutus. Comp. Biochem. Physiol. A Mol. Integr. Physiol., 150(2):159-68, 2008.

Carrier, D. \& Leon, L. R. Skeletal growth and function in the California gull (Larus californicus). J. Zool., 222(3):375-89, 1990.

Dial, K. P. Avian forelimb muscles and nonsteady flight: Can birds fly without using the muscles in their wings? Auk, 109(4):874-85, 1992.

Gatesy, S. M. \& Dial, K. P. Locomotor modules and the evolution of avian flight. Evolution, 50:331-40, 1996.

Green, A. J.; Figuerola, J. \& King, R. Comparing interspecific and intraspecific allometry in the Anatidae. J. Ornithol., 142:321-34, 2001.

Hayward, J. L.; Henson, S. M.; Banks, J. C. \& Lyn, S. L. Mathematical modeling of appendicular bone growth in glaucous-winged gulls. $J$. Morphol., 270(1):70-82, 2009.

Houck, M. A.; Gauthier, J. A. \& Strauss, R. E. Allometric scaling in the earliest fossil bird, Archaeopteryx lithographica. Science, 247:195-8, 1989.

Hutchinson, J. R. \& Gatesy, S. M. Adductors, abductors, and the evolution of archosaur locomotion. Paleobiology, 26(4):734-51, 2000.

Jackson, B. E.; Segre, P. \& Dial, K. P. Precocial development of locomotor performance in a ground-dwelling bird (Alectoris chukar): negotiating a three-dimensional terrestrial environment. Proc. Biol. Sci., 276(1672):3457-66, 2009.

Klingenberg, C. P. \& Zimmermann, M. Static, ontogenetic, and evolutionary allometry: a multivariate comparison in nine species of water striders. Am. Nat., 140(4):601-20, 1992.
Main, R. P. \& Biewener, A. A. Skeletal strain patterns and growth in the emu hindlimb during ontogeny. J. Exp. Biol., 210(Pt. 15):2676-90, 2007.

Marsh, R. L.; Ellerby, D. J.; Carr, J. A.; Henry, H. T. \& Buchanan, C. I. Partitioning the energetics of walking and running: swinging the limbs is expensive. Science, 303(5654):80-3, 2004.

Muir, G. D.; Gosline, J. M. \& Steeves, J. D. Ontogeny of bipedal locomotion: walking and running in the chick. J. Physiol., 493(Pt. 2):589-601, 1996.

Pélabon, C.; Firmat, C.; Bolstad, G. H.; Voje, K. L.; Houle, D.; Cassara, J.; Rouzic, A. L. \& Hansen, T. F. Evolution of morphological allometry. Ann. N. Y. Acad. Sci., 1320:58-75, 2014.

Picasso, M. B. J. Postnatal ontogeny of the locomotor skeleton of a cursorial bird: greater rhea. J. Zool., 286(4):303-11, 2012.

Ricklefs, R. E. Patterns of growth in birds. V. A Comparative study of development in the starling, common tern, and japanese quail. Auk, 96(1):10-30, 1979

Robertson, A. M. \& Biewener, A. A. Muscle function during takeoff and landing flight in the pigeon (Columba livia). J. Exp. Biol., 215(Pt. 23):4104-14, 2012.

Simons, E. L. Forelimb skeletal morphology and flight mode evolution in pelecaniform birds. Zoology (Jena), 113(1):39-46, 2010.

Stark, J. M. \& Ricklefs, R. E. Avian Growth and Development. New York, Oxford University Press, 1998.

Stoessel, A.; Kilbourne, B. M. \& Fischer, M. S. Morphological integration versus ecological plasticity in the avian pelvic limb skeleton. $J$. Morphol., 274(5):483-95, 2013.

Verstappen, M.; Aerts, P. \& Van Damme, R. Terrestrial locomotion in the black-billed magpie: kinematic analysis of walking, running and outof-phase hopping. J. Exp. Biol., 203(Pt. 14):2159-70, 2000.

Yang, Y.; Wang, H. \& Zhang, Z. Muscle architecture of the forelimb of the Golden Pheasant (Chrysolophus pictus) (Aves: Phasianidae) and its implications for functional capacity in flight. Avian Res., 6:3, 2015.

Zhang, Z. H. \& Yang, Y. Forelimb myology of the Golden Pheasant (Chrysolophus pictus). Int. J. Morphol., 31(4):1482-90, 2013.

Zhang, Z. H.; Vanden Berge, J. C. \& Sun, Y. H. Descriptive anatomy of the pelvic appendage myology of the endemic Chinese Grouse (Tetrastes sewerzowi). Wilson J. Ornithol., 124(2):328-37, 2012.

Correspondence to:

Zihui Zhang

Professor, College of Life Sciences

Capital Normal University

Beijing 100048

CHINA

Email: zihuizhang@cnu.edu.cn

Received: 10-10-2015

Accepted: 21-01-2016 